\title{
Triterpene glycosides defend the Caribbean reef sponge Erylus formosus from predatory fishes
}

\author{
Julia Kubanek $^{1,2}$, Joseph R. Pawlik ${ }^{2, *}$, Tegan M. Eve ${ }^{1}$, William Fenical ${ }^{1}$ \\ ${ }^{1}$ Center for Marine Biotechnology and Biomedicine, Scripps Institution of Oceanography, University of California, \\ San Diego, La Jolla, California 92093-0204, USA \\ ${ }^{2}$ Department of Biological Sciences and Center for Marine Science, University of North Carolina at Wilmington, Wilmington, \\ North Carolina 28403, USA
}

\begin{abstract}
The reef sponge Erylus formosus (Demospongiae: Geodiidae) from the Bahamas and southern Florida contains a suite of triterpene glycosides that, at a natural volumetric concentration, deters predation by the fish Thalassoma bifasciatum in laboratory assays, and a natural assemblage of reef fishes in field assays. Antifeedant metabolites were isolated by bioassay-guided fractionation of extracts of E. formosus using standard chromatographic methods and identified by nuclear magnetic resonance (NMR) spectroscopy and mass spectrometry. Included in the deterrent mixture from E. formosus collected in the Bahamas and Florida were at least 6 related triterpene glycosides possessing identical aglycones but with different sugar residues. Two additional compounds with a penasterol triterpene core (formoside, and an $N$-acetyl galactosamine derivative, formoside B) were found in specimens from the Bahamas but not Florida. Formoside, while being the major deterrent metabolite of E. formosus from the Bahamas, is less potent than the other triterpene glycosides on a weight per volume basis. As a mixture, the triterpene glycosides protect E. formosus from predatory reef fishes, but when these compounds were separated into fractions some failed to deter feeding at natural concentrations. As compounds of this type are beginning to be recognized as prevalent sponge metabolites, we suggest that terpene glycosides may have important ecological functions, just as a defensive role has been ascribed to similar compounds in sea stars, sea cucumbers, and terrestrial plants.
\end{abstract}

KEY WORDS: Sponge $\cdot$ Coral reef $\cdot$ Caribbean $\cdot$ Chemical defense $\cdot$ Predation $\cdot$ Triterpene glycosides $\cdot$ Erylus formosus $\cdot$ Formoside

\section{INTRODUCTION}

Chemical mediation of predator-prey interactions is now known to be important in benthic marine environments (for reviews see Paul 1992, Pawlik 1993). The hypothesis that marine organisms without obvious escape mechanisms or structural defenses are likely to be chemically defended has been tested with greater frequency recently, especially in ecosystems such as tropical coral reefs in which predatory pressure is intense. Of these organisms, sponges appear to be particularly well endowed with a diversity of antifeedant

*Corresponding author. E-mail: pawlikj@uncwil.edu secondary metabolites (Pawlik et al. 1988, Rogers \& Paul 1991, Albrizio et al. 1995, Pawlik et al. 1995, Chanas et al. 1996, Wilson et al. 1999). Compounds that have been shown to deter feeding by relevant potential predators include brominated pyrroles (Chanas et al. 1996, Wilson et al. 1999), brominated modified amino acids (Thompson et al. 1985) and other aromatic alkaloids (Herb et al. 1990), terpenoids (Thompson et al. 1985, Rogers \& Paul 1991), and macrolides of mixed polyketide and peptide origin (Pawlik et al. 1988).

Erylus formosus (Demospongiae: Geodiidae) is widely distributed throughout the Caribbean on shallow coral reefs. We are not aware of any reports of predation on E. formosus, despite its conspicuous presence. Pawlik 
et al. (1995) reported that organic extracts of E. formosus strongly deterred feeding by the generalist bluehead wrasse Thalassoma bifasciatum in aquarium assays. In this study, we pursued the bioassay-guided isolation and identification of chemical defenses of $E$. formosus against predatory fishes using aquarium and field assays. Here we report that triterpene glycosides are responsible for the unpalatable nature of E. formosus extracts.

\section{MATERIALS AND METHODS}

Sponge collection and identification. Specimens of Erylus formosus were collected by SCUBA at 5 to $15 \mathrm{~m}$ depth from several locations in the Bahamas and one site in Florida, and each of these collections of 1 to 5 colonies was treated separately. The sponge was identified by comparisons of spicule and tissue preparations with published accounts (Wiedenmayer 1977, cf. de Laubenfels 1953 and Pulitzer-Finali 1986). Sponge volumes of all collections were quantified by seawater displacement in a graduated cylinder. A collection of $E$. formosus $(670 \mathrm{ml})$ from Highborn Cay, Exuma Cays, Bahamas $\left(23^{\circ} 53.30^{\prime} \mathrm{N}, 75^{\circ} 83.30^{\prime} \mathrm{W}\right)$ was made in August 1995, and was used as a source of compounds for structural analyses. E. formosus from Sweetings Cay $\left(26^{\circ} 33.721^{\prime} \mathrm{N}, 77^{\circ} 52.973^{\prime} \mathrm{W}\right)(250 \mathrm{ml})$ and Black Rock ( $\left.26^{\circ} 33.852^{\prime} \mathrm{N}, 77^{\circ} 41.374^{\prime} \mathrm{W}\right)(1500 \mathrm{ml})$, both near Grand Bahama Island, collected in September 1998, was used for bioassay-guided fractionation, as was a May 1998 collection $(300 \mathrm{ml})$ from White Banks Dry Rocks, Florida Keys $\left(25^{\circ} 01.509^{\prime} \mathrm{N}, 80^{\circ} 23.604^{\prime} \mathrm{W}\right)$. Four collections from September 1998 were used for comparisons of chemical composition and feeding deterrence within this species: Sweetings Cay $(300 \mathrm{ml})$, Black Rock (300 ml), Samana Cay, Southeastern Bahamas $\left(23^{\circ} 23.380^{\prime} \mathrm{N}, 73^{\circ} 42.986^{\prime} \mathrm{W}\right)(250 \mathrm{ml})$, and Chubb Cay, Berry Islands, Bahamas $\left(25^{\circ} 01.509^{\prime} \mathrm{N}\right.$, $\left.80^{\circ} 23.604^{\prime} \mathrm{W}\right)(250 \mathrm{ml})$.

Isolation and structural identification of antifeedant compounds. General chemical methods and instrumentation are described in Kubanek et al. (2000). Following collection and volume measurements, specimens were stored in a freezer at $-20^{\circ} \mathrm{C}$ until ready for analysis. At this time, sponges were freeze-dried, and a small sample was removed for spicule analysis. Freeze-dried sponge material was extracted repeatedly with methanol and methanol/dichloromethane (1:1), and the extracts were concentrated in vacuo and combined. The crude extracts were assayed for effects on feeding by the generalist wrasse Thalassoma bifasciatum, as described below, as were all subsequent fractions, and deterrent fractions were subjected to further fractionation.
Bioassay-guided fractionation of deterrent extracts was accomplished as described in Kubanek et al. (2000). Summarized briefly, solvent partitioning between $n$-butanol and water was followed by reversed-phase vacuum liquid chromatography of the $n$-butanol soluble constituents, yielding a triterpene glycoside-rich fraction for each collection. These were further purified by reversed-phase flash-column chromatography and reversed-phase HPLC using methanol/water or acetonitrile/water mixtures as eluents. Structure determination was accomplished by NMR and mass spectral analyses, and by GC analysis of hydrolyzed and derivatized saccharides (Kubanek et al. 2000).

Feeding deterrence assays. Aquarium assays using a generalist predatory reef fish, the bluehead wrasse Thalassoma bifasciatum, were conducted as previously described (Pawlik \& Fenical 1992, Pawlik et al. 1995). Each extract or compound to be tested $(10 \mathrm{ml}$ equiv) was dissolved in a minimum amount of appropriate solvent, and $0.3 \mathrm{~g}$ sodium alginate and $0.5 \mathrm{~g}$ freeze-dried powdered squid mantle and water were added to yield a final volume of $10 \mathrm{ml}$. This mixture was homogenized and then loaded into a $10 \mathrm{ml}$ syringe, and the paste squeezed into a $0.25 \mathrm{~mol} \mathrm{l}^{-1}$ solution of calcium chloride, creating a spaghetti-like strand of squid food in which extracts or compounds were incorporated at appropriate concentrations. The food was rinsed and chopped into $4 \mathrm{~mm}$-long pellets with a razor blade. Control pellets were made without the addition of sponge extracts or compounds but with the solvent used in treatment assays, and occasionally with the addition of food coloring to both treatment and control pellets to mask coloration of sponge extracts. Control and then treatment pellets were offered in this order to each cell of assay fish. Each of 10 cells contained between 3 and 6 fish (at least one in the blue phase, and most others in yellow phase) that were fed a diet of control pellets each day. The ecological relevance of using of $T$. bifasciatum in aquarium assays has been discussed in Pawlik et al. $(1987,1995)$. A food pellet was considered rejected if not eaten after a minimum of 3 attempts by one or more fish to take it into their mouth cavity, or if the pellet was approached and ignored after one such attempt. The significance of differences in the consumption of treated versus control pellets was evaluated with the Fisher exact test (Zar 1984). For any single assay of 10 replicates, an extract was considered significantly deterrent if 4 or more of the pellets were rejected $(\mathrm{p} \leq 0.043$, 1-tailed test); therefore, in judging the mean deterrence of individual assays, an extract, fraction, or pure compound was considered deterrent if the mean number of pellets eaten was less than or equal to 6 .

Purified fractions from Sweetings Cay, Highborn Cay, and the Florida Keys were tested at multiple con- 
centrations in aquarium feeding assays. For each fraction, the concentration designated as natural concentration was the highest concentration of that fraction that had been isolated from a collection (HPLC fraction A: $0.39 \mathrm{mg} \mathrm{ml}^{-1}$; HPLC B: $0.41 \mathrm{mg} \mathrm{ml}^{-1}$; HPLC C: $0.036 \mathrm{mg} \mathrm{ml}^{-1}$; formoside: $7.9 \mathrm{mg} \mathrm{ml}^{-1}$; formoside $\mathrm{B}$ : $0.052 \mathrm{mg} \mathrm{ml}^{-1}$ ). Assays were performed in triplicate and at 3 different concentrations for each fraction. Effects of treatments on feeding relative to controls (10 pellets each) were determined using 1-tailed Student's paired $t$-tests. The relationship between concentration and deterrence was assessed by correlation and linear regression analysis (Zar 1984). Triplicate aquarium assays were also performed on combinations of purified fractions each at natural concentration. Differences in mean feeding deterrence (proportion of total pellets eaten) were tested with 1-way analysis of variance (ANOVA) on arcsine-transformed data to meet the assumptions of ANOVA (Sokal \& Rohlf 1981). The Tukey-Kramer HSD test was applied a posteriori to determine which treatments resulted in different mean feeding deterrence at the 0.05 level of significance (Zar 1984). Analyses were conducted on JMP software.

Field assays were conducted according to the method used in Hay (1984) (assay design), and Pawlik \& Fenical (1992) and Chanas \& Pawlik (1995) (assay food preparation). Extracts or compounds from Erylus formosus were incorporated at natural volumetric concentrations into carageenan strips that contained squid mantle as a protein source. Paired treatment and control strips were then placed on shallow $(<15 \mathrm{~m})$ reefs in the Bahamas. Twenty replicate ropes, each with a treatment and control strip attached, were offered to the natural assemblage of fishes until half or more of one food strip from each was eaten, or $2 \mathrm{~h}$ passed, whichever came first. Amounts eaten were measured using a ruler, and data were analyzed using the Wilcoxon paired sample test (1-tailed, Zar 1984) after excluding pairs for which either all or none of both strips had been consumed.

\section{RESULTS}

The crude extracts of Erylus formosus significantly deterred feeding in aquarium and field assays (Table 1, Fig. 1). Solvent-partitioning of crude extracts of $E$. formosus from several independent collections and extractions concentrated the deterrent components in $n$-butanol rather than water (Tables 1 to 3 , Fig. 2). Vacuum liquid chromatography using reversedphase silica gel was performed on the $n$-butanol-soluble materials, yielding a terpene glycoside-rich fraction for extracts from each location. Table 4 shows the variable yield of total terpene glycosides from different
Table 1. Feeding by Thalassoma bifasciatum in aquarium assays using natural concentrations of extracts and fractions of Erylus formosus from Sweetings Cay, Bahamas collected in 1998

\begin{tabular}{|lc|}
\hline Sample & \multicolumn{2}{c}{$\begin{array}{c}\text { Pellets eaten (of 10) } \\
\text { 1 } \times \text { natural concentration }\end{array}$} \\
\hline Crude extract & 0 \\
Water-partition of crude extract & 9 \\
n-butanol partition of crude extract & 0 \\
Water eluate of vacuum column & 10 \\
Methanol eluate of vacuum column & 2 \\
Column fraction & A \\
& 10 \\
B & 6 \\
C & 7 \\
E & 4 \\
F & 3 \\
G & 6 \\
B + C & 10 \\
C + D & 2 \\
D + E & 1 \\
\hline
\end{tabular}

locations and collections of E. formosus. Each of these mixtures was characterized by ${ }^{1} \mathrm{H}$ NMR and was found to consist of a complex suite of triterpene glycosides with no other hydrogen-bearing compounds in evidence (i.e. organic components of mixtures contained $>95 \%$ terpene glycosides). NMR spectral analysis of these mixtures indicated that a known triterpene glycoside, formoside (Fig. 3; and Jaspars \& Crews 1994), was the major metabolite in fractions from Sweetings Cay, Chubb Cay, and Black Rock. The terpene glycoside-rich fraction from Samana Cay also contained formoside, but in lesser quantity, and contained other compounds in greater quantities. The terpene glycoside-rich mixture from Key Largo, Florida did not contain formoside, but did contain a number of other triterpene glycosides. Each of these terpene glycoside-rich fractions was assayed in an aquarium assay and was found to significantly deter feeding by Thalassoma

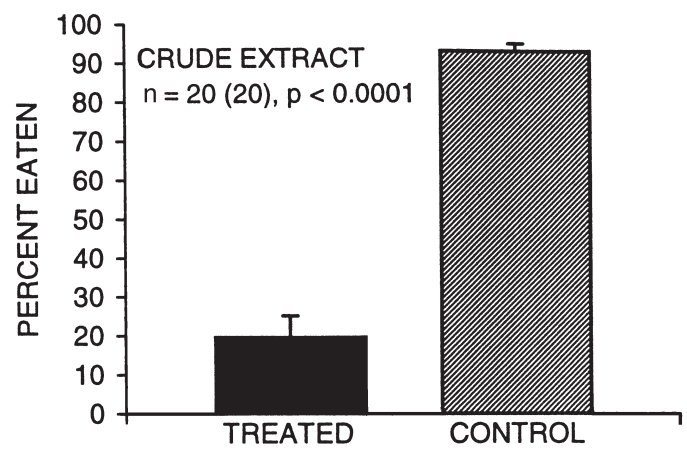

Fig. 1. Erylus formosus. Field assay of crude extract (Highborn Cay, Bahamas, 1995). Error bars in this and subsequent figures show $1 \mathrm{SE}$ 


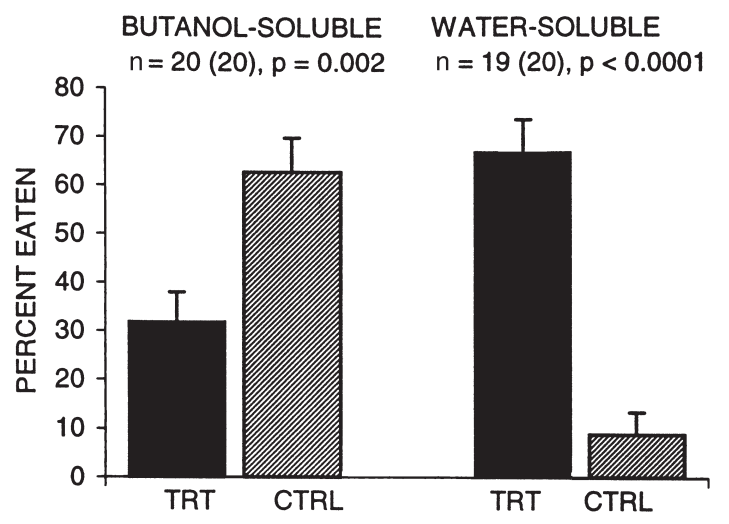

Fig. 2. Erylus formosus. Field assay of solvent partitions (Highborn Cay, Bahamas, 1995). TRT: treated; CTRL: control

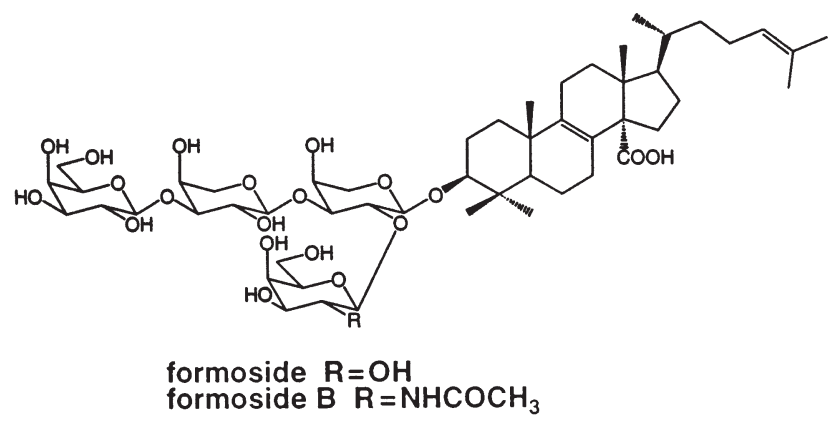<smiles>CC(C)C(C)(O)CC[C@H](C)C1CC[C@]2(O)C3=C(CC[C@]12C)[C@@]1(C)CC[C@H](O)C(C)(C)C1CC3</smiles>

triterpene glycosides present in HPLC fractions A, B, C ( $R, R^{\prime}=$ saccharides)

\begin{tabular}{lccc} 
& \multicolumn{3}{c}{ saccharides (mole \%): } \\
& HPLC A & HPLC B & HPLC C \\
arabinose & 38.3 & 39.1 & 73.1 \\
xylose & 2.4 & 3.5 & 18.2 \\
galactose & 15.4 & 23.7 & 3.4 \\
glucose & 17.8 & 5.7 & 2.4 \\
N-acetyl & 18.2 & 16.5 & 2.9 \\
glucosamine & & & \\
unknown & 7.9 & 11.5 & -
\end{tabular}

Fig. 3. Erylus formosus. Antifeedant metabolites

bifasciatum (Tables 1 to 4). The terpene glycoside-rich mixture from $E$. formosus collected at Black Rock in the Bahamas also deterred feeding by a natural assemblage of reef fishes in field assays (Fig. 4).
Table 2. Feeding by Thalassoma bifasciatum in aquarium assays using natural concentrations of extracts and fractions of Erylus formosus from Black Rock, Bahamas collected in 1998

\begin{tabular}{|c|c|c|}
\hline Sample & $\begin{array}{c}\text { Pellets ea } \\
1 \times \text { natural } \\
\text { conc. }\end{array}$ & $\begin{array}{c}2 \times \text { natural } \\
\text { conc. }\end{array}$ \\
\hline Water-partition of crude extract & 9 & \\
\hline$n$-butanol partition of crude extract & 2 & \\
\hline Water eluate of vacuum column & 10 & \\
\hline Methanol eluate of vacuum column & 4 & \\
\hline Column fraction $\mathrm{A}$ & 9 & 7 \\
\hline $\mathrm{B}$ & 8 & 1 \\
\hline $\mathrm{C}$ & 8 & 2 \\
\hline $\mathrm{D}$ & 10 & 2 \\
\hline $\mathrm{E}$ & 10 & 3 \\
\hline $\mathrm{F}$ & 10 & 5 \\
\hline $\mathrm{G}$ & 10 & 1 \\
\hline All column fractions recombined & 2 & \\
\hline
\end{tabular}

Table 3. Feeding by Thalassoma bifasciatum in aquarium assays using natural concentrations of extracts and fractions of Erylus formosus from Key Largo, Florida collected in 1998

\begin{tabular}{|lc|}
\hline Sample & $\begin{array}{c}\text { Pellets eaten (of 10) } \\
1 \times \text { natural concentration }\end{array}$ \\
\hline Water-partition of crude extract & 10 \\
$n$-butanol partition of crude extract & 1 \\
Water eluate of vacuum column & 10 \\
Methanol eluate of vacuum column & 4 \\
Column fraction A & 7 \\
B + C + D & 6 \\
E & 8 \\
F & 10 \\
\hline
\end{tabular}

The terpene glycoside-rich fractions from 3 collections were fractionated using reversed-phase flashcolumn chromatography. In most cases, this separation yielded 7 fractions (column fractions A to G) with distinct constituents, although components of some fractions overlapped. Analysis by NMR spectroscopy indicated that triterpene glycosides were concentrated in column fractions B to F (B to E for Key Largo collection). Fractions were assayed separately and in combination (Tables 1 to 3 ).

Fractions B to F collected from the reversed-phase flash column that deterred feeding alone or in combination contained mixtures of closely related triterpene glycosides, as determined by NMR spectroscopy. Further purification of these triterpene glycoside mixtures was achieved by reversed-phase HPLC. From column fractions $D, E$, and $F$, formoside was purified to approximately $99 \%$ from Bahamian extracts, as was a previously unknown but related metabolite, formoside B (Fig. 3; Kubanek et al. 2000). These 2 compounds were absent from the Florida collection of Erylus formosus. Column fractions $\mathrm{B}$ and $\mathrm{C}$ were purified by repetitive 


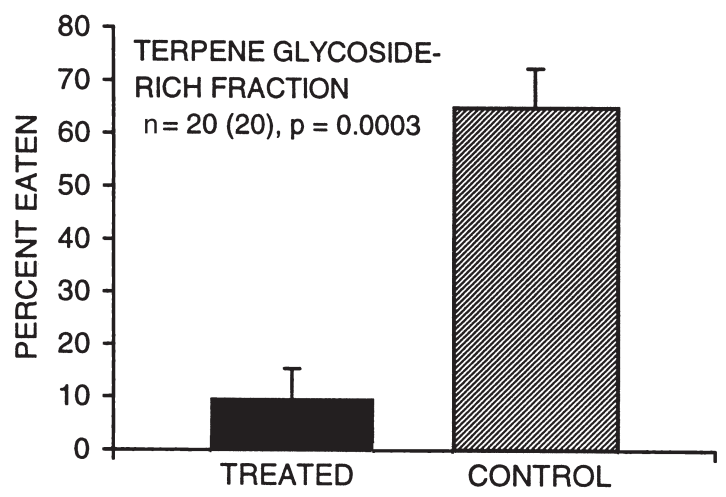

Fig. 4. Erylus formosus. Field assay of terpene glycoside-rich fraction (Black Rock, Bahamas, 1998)

HPLC to yield fractions containing closely related compounds, called HPLC fractions A, B, and C (only HPLC $\mathrm{A}$ and $\mathrm{B}$ from $E$. formosus from the Bahamas). Diodearray HPLC analysis and NMR spectral analysis indicated that each of HPLC fractions A, B, and C contained 2 major compounds and a number of more minor constituents. Chemical degradation experiments and further spectroscopic analysis revealed that the terpene glycosides from these 3 fractions all contained the same unusual triterpene core (Fig. 3; Kubanek et al. 2000). Mass spectral data coupled with degradative carbohydrate analysis showed that the 2 major compounds in HPLC fractions A and B were hexasaccharides, while the 2 in HPLC fraction C were trisaccharides. Fig. 3 shows the saccharides present in each fraction. Further efforts to separate the closely related pairs of compounds in HPLC fractions A to C proved fruitless.

Fig. 5 shows the results of assays using the pure compounds formoside and formoside $B$, and HPLC fractions $\mathrm{A}, \mathrm{B}$, and $\mathrm{C}$, separately and at different concentrations. Formoside, HPLC A, and HPLC B all deterred fish feeding at or close to their natural concentrations $\left(7.9 \mathrm{mg} \mathrm{ml}^{-1}, 0.39 \mathrm{mg} \mathrm{ml}^{-1}\right.$, and $0.41 \mathrm{mg}$ $\mathrm{ml}^{-1}$, respectively) relative to controls ( $\mathrm{p}-$ values shown in Fig. 5). These compounds showed a negative correlation between concentration and food consumed $(-0.85<\mathrm{r}$ $<-0.72$ for HPLC A, B, and formoside), with a significant linear regression for each when tracking food consumption as a function of metabolite concentration (HPLC A p $=0.0004$, HPLC B p $=0.008$, formoside $\mathrm{p}=$ 0.004). Analysis of variance followed by the Tukey-Kramer HSD test applied to the concentration-related data in Fig. 5 indicated that HPLC A and B at all concentrations tested (1 to 4 times natural concentration; 0.39 to $1.64 \mathrm{mg} \mathrm{ml}^{-1}$ ) were similarly deter-

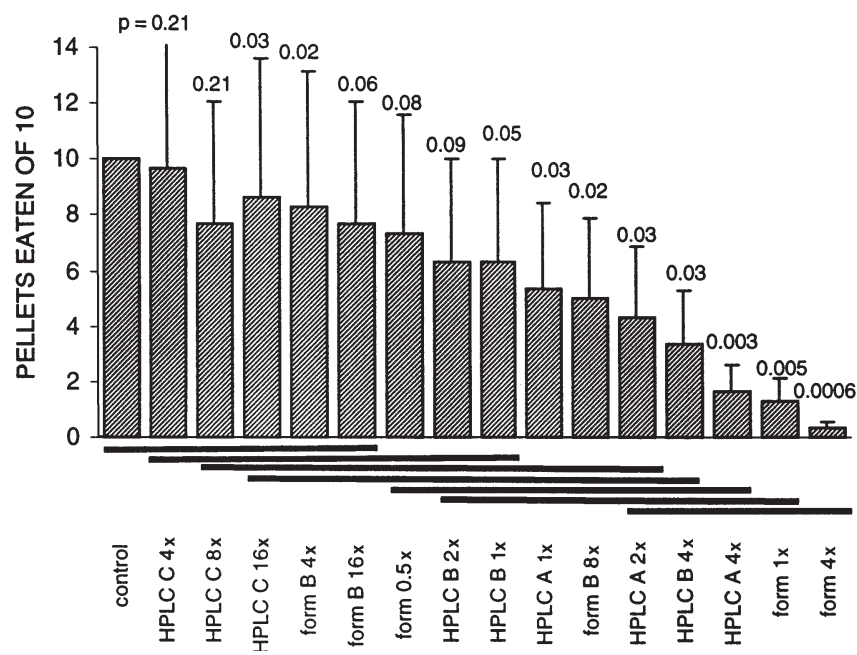

Fig. 5. Erylus formosus. Aquarium assay results of purified triterpene glycosides from sponge at various multiples of natural concentration (all $n=3$ ). $p$-values shown above each bar refer to paired Student's $t$-tests between treatments listed and controls. Horizontal lines under histograms overlap treatments that do not significantly differ in their palatabilities (Tukey-Kramer HSD test, $\mathrm{p}<0.05$ )

rent to formoside at 0.5 and 1 times the natural concentration ( 4.0 to $7.9 \mathrm{mg} \mathrm{m}^{-1}$ ). Formoside B (natural concentration $=0.052 \mathrm{mg} \mathrm{ml}^{-1}$ ) and HPLC C (natural concentration $=0.036 \mathrm{mg} \mathrm{ml}^{-1}$ ) were significantly deterrent at some concentrations much higher than natural concentrations but not others, and their effects on feeding did not correlate well with concentrations at the levels tested (formoside B linear regression $\mathrm{p}=$ 0.16 , HPLC $p=0.35$ ).

Aquarium assay results of combinations of these compounds and fractions are shown in Fig. 6. Using the Tukey-Kramer HSD test, all combinations that contained formoside at its maximum known natural concentration $\left(7.9 \mathrm{mg} \mathrm{ml}^{-1}\right)$ were found to be significantly more deterrent than all combinations that did not con-

Table 4. Erylus formosus. Geographic variation in terpene glycoside-rich fraction and feeding deterrence of extracts

\begin{tabular}{|lccc|}
\hline Sponge origin & Date & $\begin{array}{c}\text { mg total terpene } \\
\text { glycosides } \\
\text { per ml sponge }\end{array}$ & $\begin{array}{c}\text { Pellets } \\
\text { eaten } \\
\text { (of 10) }\end{array}$ \\
\hline Key Largo, Florida & May 1998 & 7.2 & 4 \\
Sweetings Cay, Bahamas & Sep 1998 & 14 & 1 \\
Chubb Cay, Bahamas & Sep 1998 & 2.4 & 2 \\
Samana Cay, Bahamas & Sep 1998 & 5.0 & 3 \\
$\begin{array}{l}\text { Black Rock, Bahamas } \\
\quad \text { (1 clone) }\end{array}$ & Sep 1998 & 22 & 4 \\
$\begin{array}{c}\text { Black Rock, Bahamas } \\
\text { (mixture of clones) }\end{array}$ & Sep 1998 & 15 & 1 \\
\hline
\end{tabular}




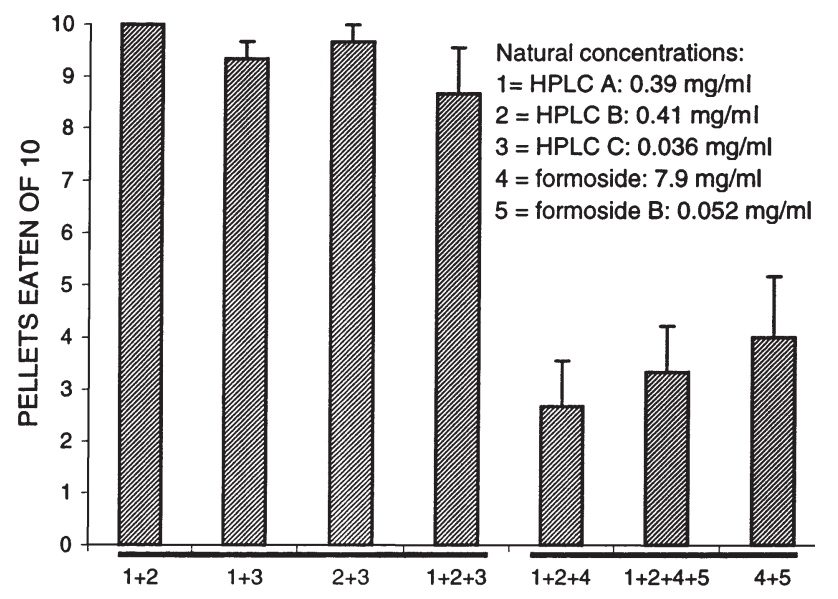

Fig. 6. Erylus formosus. Aquarium assay results of combinations of purified triterpene glycosides, each at natural concentration (all $n=3)$. Metabolites were combined as they occur in populations of E. formosus in the Bahamas and Florida. Horizontal line under histograms overlaps combinations that do not significantly differ in their palatabilities (Tukey-Kramer HSD test, $\mathrm{p}<0.05$

tain formoside. These assays were run separately from those in Fig. 5 and so differences between those 2 data sets cannot be assessed.

\section{DISCUSSION}

Bioassay-guided fractionation of extracts of Erylus formosus from several locations in the Bahamas and 1 location in Florida revealed that a group of triterpene glycosides is responsible for the unpalatability of this sponge to Caribbean reef fishes. Two pure triterpene glycosides, formoside and formoside $\mathrm{B}$, and 3 mixtures of closely related triterpene glycosides, HPLC fractions A, B, and C, were obtained (Fig. 3).

Formoside, HPLC A, and HPLC B all deterred fish (Thalassoma bifasciatum) feeding relative to controls within a range of 1 to 4 times natural concentrations, while formoside $\mathrm{B}$ and HPLC $\mathrm{C}$ showed negligible effects at concentrations up to 16-fold higher than natural (Fig. 5). At natural concentrations, formoside, HPLC A, and HPLC B were similarly deterrent (Fig. 5); however, the natural concentration of formoside measured from Bahamian specimens of Erylus formosus was as high as $7.9 \mathrm{mg} \mathrm{ml}^{-1}$, whereas for the others the natural concentration was 0.39 to $0.41 \mathrm{mg} \mathrm{ml}^{-1}$. Formoside had a statistically indistinguishable effect at 4.0 to $7.9 \mathrm{mg}^{-1}$ from HPLC A and B at concentrations of 0.39 to $1.6 \mathrm{mg} \mathrm{ml}^{-1}$, suggesting that formoside is less potent on a weight per volume basis than the compounds present in HPLC A and B. Although formoside B and HPLC C showed no concentration-dependent deter- rence at up to 16 times the natural concentration, the highest concentrations tested were only 0.83 and $0.58 \mathrm{mg} \mathrm{ml}^{-1}$, respectively. The small quantities of isolated material prevented testing above 16 -fold. Therefore, we conclude that formoside is responsible for most of the chemical deterrence of E. formosus extracts because of its high concentration, but that minor constituents in HPLC A and B also contribute to the deterrence of this sponge and are, in fact, more potent on a per molecule basis.

Terpene glycosides have rarely been encountered in marine sponges. The few sponges that are known to contain triterpene or steroidal glycosides have come from the demosponge orders Astrophorida/Choristida (Asteropus sarasinosum, Kitagawa et al. 1987, Kobayashi et al. 1991; Erylus spp., see below), Halichondrida (Ulosa sp., Antonov et al. 1994, 1998), and Axinellida (Ectyoplasia ferox, Cafieri et al. 1999). Of these, sponges of the genus Erylus have yielded a large number (approx. 8 of 21) of the known sponge terpene glycosides. Erylosides A to F (excluding B) were isolated from E. lendenfeldi (Carmely et al. 1989), Erylus sp. (D'Auria et al. 1992), E. goffrilleri (Gulavita et al. 1994), and E. formosus (Stead et al. 2000). Despite the consistent naming of these compounds, the erylosides represent 3 different aglycone carbon skeletons and are quite distinct in their patterns of glycosylation. As discussed earlier, formoside was also reported as a triterpene glycoside from E. formosus (Jaspars \& Crews 1994). Eryloside F shares the penasterol aglycone with formoside. The parent triterpene, penasterol, was isolated from the astrophorid/choristid sponge Penares sp. (Cheng et al. 1988).

Because terpene glycosides are quite polar and present difficulties during purification (including foaming), it seems reasonable to suppose that naturalproduct chemists have only begun to prioritize determination of their prevalence and structural diversity across sponge taxa. These compounds have been reported to possess interesting pharmacological activities, such as cytotoxicity (Cafieri et al. 1999), immunosuppressive activity (Gulavita et al. 1994), and thrombin receptor antagonist activity (Stead et al. 2000). However, until now there have been no published reports of the ecological roles of these compounds, and no discussion in the literature of the chemical defenses of these sponges except in the survey of crude extracts by Pawlik et al. (1995).

The soapy character of steroidal and triterpene glycosides may assist in keeping these compounds at the interface of sponge tissue and seawater, where they can most readily be contacted by potential predators. These compounds possess a lipophilic core (the steroid or triterpene aglycone) and 1 or more hydrophilic portions (the saccharides). Similar metabolites from terrestrial 
plants are believed to cause digestive problems in large herbivores such as cattle by altering the surface tension of stomach contents, thereby trapping gas produced by bacterial fermentation (Applebaum \& Birk 1979). However, the soapy character of triterpene glycosides does not in itself explain the ecological activity that we observed in this study, because of the variation in concentration-dependent potencies in triterpene glycosides with different molecular structures (Figs. 3 \& 5).

The physiological mechanisms by which chemical defenses affect consumers' feeding behavior are largely unknown, although acute toxicity (e.g. Huntley et al. 1986, Ives 1987), reduction of digestive efficiency (e.g. Boettcher \& Targett 1993), and decreased reproductive success (e.g. Poulet et al. 1994, Lindquist \& Hay 1995) have been investigated in marine systems. Some metabolites have been shown to reduce herbivore or predator growth rates (Hay et al. 1987, Pennings \& Carefoot 1995) and survivorship (Paul \& Fenical 1986), although the molecular or cellular mechanisms by which this occurs remain elusive. Previous investigations of the pharmacological potential of erylosides E and $\mathrm{F}$ isolated from Erylus spp. indicated that these compounds caused significant cellular calcium release (A. Wright pers. comm.). Calcium release and subsequent cascading physiological effects may play a role in the feeding deterrence of Erylus spp. triterpene glycosides, but this hypothesis remains to be tested.

We observed some important geographic variation in the quantity and identity of terpene glycosides in Erylus formosus collected at different sites. Total terpene glycosides of 6 sponge collections from 5 locations varied between 2 and $22 \mathrm{mg}$ terpene glycosides $\mathrm{ml}^{-1}$ fresh sponge tissue (Table 4). NMR spectral analysis showed that $E$. formosus collected in the Bahamas at Sweetings Cay, Chubb Cay, Samana Cay, Black Rock, and Highborn Cay all contained formoside as discussed above, present as approx. $90 \%$ of total terpene glycosides at most Bahamian sites studied. The sample from Samana Cay, Bahamas, contained lesser quantities of formoside, although it was still a prominent metabolite in the terpene glycoside mixture. The collection of E. formosus made in the Florida Keys contained no detectable amount of formoside. However, the total terpene glycoside concentration $\left(7.2 \mathrm{mg} \mathrm{ml}^{-1}\right.$ sponge) for the Florida sample was similar to that of other locations, and this fraction deterred fish from feeding (Table 4). Because of the consistent feeding deterrence of total triterpene glycoside mixtures from any given sponge collection that appears independent of compound composition, it must be concluded that any 1 compound is not essential for the chemical defense of this sponge. Increases in metabolite concentration resulted in more pronounced effects on feeding (Fig. 5). Thus, simply increasing the overall concentration of terpene glycosides, even if the mixture does not contain the entire suite of natural compounds, appears to provide protection against fish predation. When direct comparisons were made of combinations of compounds, each present at its natural concentration, only the presence or absence of formoside, the most concentrated compound, caused a significant difference in deterrence (Fig. 6). If the metabolites were acting synergistically, one would expect that certain combinations would be more deterrent than the summed effects of individual components, but this was not observed.

The geographic variation in chemical composition raises the possibility that there is a group of closely related species of Erylus in the Caribbean. The description of E. formosus by Wiedenmayer (1977) has since been separated by Pulitzer-Finali (1986) into $E$. bahamensis in the Bahamas and Dominican Republic and E. clavatus in Jamaica on the basis of small differences in spicule size and morphology. Like others who have studied the chemistry of this sponge (Jaspars \& Crews 1994, Stead et al. 2000), we identified our specimens as E. formosus because of similarities in gross morphology, and a continuous gradation in spicule morphology that made distinctions between E. bahamensis and E. clavatus seem ambiguous. A possible geographic correlation between the chemical variation observed in this study and small differences in spicule morphology was not addressed herein, but may warrant future attention. The documentation of chemical composition over a wider geographic range may provide a chemotaxonomic reference to add to morphological characteristics in helping to resolve uncertainty in species identification.

Marine steroidal and triterpene glycosides have mainly been reported from echinoderms, specifically from the Asteroidea (sea stars), which possess steroidal glycosides, and the Holothuroidea (sea cucumbers), which possess triterpene glycosides (Stonik \& Elyakov 1988). Although it has been suggested that these compounds play a defensive role in echinoderms, experimental evidence is inconclusive and mostly related to seasonal fluctuations in metabolite levels and varying concentrations in different echinoderm tissues (Burnell \& ApSimon 1983, Stonik \& Elyakov 1988). Bingham \& Braithwaite (1986) used an assay to demonstrate the toxicity of holothurian triterpene glycosides against fishes, but reported no effect of the compounds on predators in feeding assays. One study supporting a defensive hypothesis was that of Lucas et al. (1979), in which planktivorous fishes were deterred from feeding on foods laced with partially-purified steroidal glycosides from the crown-of-thorns sea star Acanthaster planci, and its larvae. Despite limited experimental evidence using echinoderm metabolites, steroidal and triterpene glycosides have been widely assumed to 
play a defensive role for echinoderms, analogous to similar metabolites found in terrestrial plants (Applebaum \& Birk 1979). These compounds have more recently been found in taxonomically distant organisms such as soft corals (e.g. Kittakoop et al. 1999) and amphipods (N. Lindquist pers. comm.). The application of ecologically relevant bioassays and chemical fractionation procedures may reveal further evidence of defensive functions of marine terpene glycosides.

This report is the first account of sponge terpene glycosides functioning as fish feeding-deterrents. In a parallel study, preliminary evidence indicates that terpene glycosides defend Mycale laxissima (order Poecilosclerida) from fish predation (Kubanek et al. unpubl.), and that triterpene glycosides at natural concentrations from Ectyoplasia ferox (Cafieri et al. 1999) are also deterrent (Kubanek et al. unpubl. data). It is reasonable to suppose that similar compounds may function likewise in many sponges, although based on the structure-activity relationships noted herein, one should be watchful for differences in ecological activity based upon subtle variations in chemical structure.

Acknowledgements. This research was made possible by NSF grants OCE-9711255 to J.R.P. and CHE-9807098 to W.F., and by an NSERC (Canada) postdoctoral fellowship to J.K. We thank the captain and crew of the RV 'Seward Johnson' and RV 'Edwin Link', and the staff of the National Undersea Research Center in Key Largo, Florida, for their cooperation. We thank Gregory McFall, Monica Puyana, Brett Waddell, Will O'Neal, and Kristen Whalen for assistance with sponge collections and with assays. Shannon O'Brien and Lindsay Shaffer assisted with extractions and fractionation, Dr Parastoo Azadi at the University of Georgia Complex Carbohydrate Research Center performed carbohydrate analysis, and Timothy Henkel conducted statistical analyses. Helpful discussions relating to metabolites of Erylus formosus were held with Paul Stead at GlaxoWellcome, UK, and Amy Wright of Harbor Branch Oceanographic Institution. We are grateful to the government of the Bahamas for permission to perform research in their territorial waters. This is contribution no. 252 of UNCW's Center for Marine Science Research.

\section{LITERATURE CITED}

Albrizio S, Ciminiello P, Fattorusso E, Magno S, Pawlik JR (1995) Amphitoxin, a new high molecular weight antifeedant pyridinium salt from the Caribbean sponge Amphimedon compressa. J Nat Prod 58:647-652

Antonov AS, Kalinosvkii AI, Stonik VA, Evtushenko EV, Elyakov GB (1994) Structure of ulososide A, a new triterpenoid glycoside from the Ulosa sp. sponge. Russ Chem Bull 43:1265-1269

Antonov AS, Kalinosvkii AI, Stonik VA (1998) Ulososide B, a new unusual norlanostane-triterpene glycoside and its genuine aglycone from the Madagascar sponge Ulosa sp. Tetrahedron Lett 39:3807-3808

Applebaum SW, Birk Y (1979) Saponins. In: Rosenthal GA, Janzen DH (eds) Herbivores: their interaction with secondary plant metabolites. Academic Press, New York, p 539-566
Bingham BL, Braithwaite LF (1986) Defense adaptations of the dendrochirote holothurian Psolus chitonoides Clark. J Exp Mar Biol Ecol 98:311-322

Boettcher AA, Targett NM (1993) Role of polyphenolic molecular size in reduction of assimilation efficiency in Xiphister mucosus. Ecology 74:891-903

Burnell DJ, ApSimon JW (1983) Echinoderms. In: Scheuer PJ (ed) Marine natural products, Vol 5. Academic Press, New York, p 287-389

Cafieri F, Fattorusso E, Taglialatela-Scafati O (1999) Ectyoplasides A - B-unique triterpene oligoglycosides from the Caribbean sponge Ectyoplasia ferox. Eur J Org Chem: 231-238

Carmely S, Roll M, Loya Y, Kashman Y (1989) The structure of eryloside A, a new antitumor and antifungal 4-methylated steroidal glycoside from the sponge Erylus lendenfeldi. J Nat Prod 52:167-170

Chanas B, Pawlik JR (1995) Defenses of Caribbean sponges against predatory reef fish. II. Spicules, tissue toughness, and nutritional quality. Mar Ecol Prog Ser 127:195-211

Chanas B, Pawlik JR, Lindel T, Fenical W (1996) Chemical defense of the Caribbean sponge Agelas clathrodes (Schmidt). J Exp Mar Biol Ecol 208:185-196

Cheng J, Kobayashi J, Nakamura H, Ohizumi Y, Hirata Y, Sasaki T (1988) Penasterol, a novel antileukemic sterol from the Okinawan marine sponge Penares sp. J Chem Soc Perkin Trans I:2403-2406

D'Auria MV, Paloma LG, Minale L, Riccio R (1992) Structure characterization by two-dimensional NMR spectrometry, of two marine triterpene oligoglycosides from a Pacific sponge of the genus Erylus. Tetrahedron 48:491-498

de Laubenfels MW (1953) Sponges from the Gulf of Mexico. Bull Mar Sci Gulf Caribb 2:511-549

Gulavita NK, Wright AE, Kelly-Borges M, Longley RE (1994) Eryloside E from an Atlantic sponge Erylus goffrilleri. Tetrahedron Lett 35:4299-4302

Hay ME (1984) Patterns of fish and urchin grazing on Caribbean coral reefs: are previous results typical? Ecology 65:446-454

Hay ME, Duffy JE, Pfister CA, Fenical W (1987) Chemical defenses against difference marine herbivores: are amphipods insect equivalents? Ecology 68:1567-1580

Herb R, Carroll AR, Yoshida WY, Scheuer PJ, Paul VJ (1990) Polyalkylated cyclopentindoles: cytotoxic fish antifeedants from a sponge, Axinella sp. Tetrahedron 46: 3089-3092

Huntley M, Sykes P, Rohan S, Marin V (1986) Chemically-mediated rejection of dinoflagellate prey by the copepods Calanus pacificus and Paracalanus parvus: mechanism, occurrence and significance. Mar Ecol Prog Ser 28:105-120

Ives JD (1987) Possible mechanisms underlying copepod grazing responses to levels of toxicity in red tide dinoflagellates. J Exp Mar Biol Ecol 112:131-145

Jaspars M, Crews P (1994) A triterpene tetrasaccharide, formoside, from the Caribbean Choristida sponge Erylus formosus. Tetrahedron Lett 35:7501-7504

Kitagawa I, Kobayashi M, Okamoto Y, Yoshikawa M, Hamamoto Y (1987) Structures of sarasinosides $A_{1}, B_{1}$, and $C_{1}$; new norlanostane-triterpenoid oligoglycosides from the Palauan marine sponge Asteropus sarasinosum. Chem Pharm Bull 35:5036-5039

Kittakoop P, Suttisri R, Chaichantipyuth C, Vethchagarun S, Suwanborirux K (1999) Norpregnane glycosides from a Thai soft coral, Scleronephthya pallida. J Nat Prod 62: 318-320

Kobayashi M, Okamoto Y, Kitagawa I (1991) Marine Natural Products. XXVIII. The structures of sarasinosides 
$\mathrm{A}_{1}, \mathrm{~A}_{2}, \mathrm{~A}_{3}, \mathrm{~B}_{1}, \mathrm{~B}_{2}, \mathrm{~B}_{3}, \mathrm{C}_{1}, \mathrm{C}_{2}, \mathrm{C}_{3}$, nine new norlanostanetriterpenoid oligoglycosides from the Palauan marine sponge Asteropus sarasinosum. Chem Pharm Bull 39: 2867-2877

Kubanek J, Fenical W, Pawlik JR (2000) New antifeedant triterpene glycosides from the Caribbean sponge Erylus formosus. Nat Prod Lett (in press)

Lindquist N, Hay ME (1995) Can small rare prey be chemically defended? The case for marine larvae. Ecology 76 : $1347-1358$

Lucas JS, Hart RJ, Howde ME, Salathe R (1979) Saponins in eggs and larvae of Acanthaster planci (L.) (Asteroidea) as chemical defenses against planktivorous fish. J Exp Mar Biol Ecol 40:155-165

Paul VJ (1992) Chemical defenses of benthic marine invertebrates. In: Paul VJ (ed) Ecological roles of marine natural products. Comstock Publishing Associates, Ithaca, NY, p $164-188$

Paul VJ, Fenical W (1986) Chemical defense in tropical green algae, order Caulerpales. Mar Ecol Prog Ser 34:157-169

Pawlik JR (1993) Marine invertebrate chemical defenses. Chem Rev 93:1911-1922

Pawlik JR, Fenical W (1992) Chemical defense of Pterogorgia anceps, a Caribbean gorgonian coral. Mar Ecol Prog Ser 87:183-188

Pawlik JR, Burch MT, Fenical W (1987) Patterns of chemical defense among Caribbean gorgonian corals: a preliminary survey. J Exp Mar Biol Ecol 108:55-66

Pawlik JR, Kernan MR, Molinski TF, Harper MK, Faulkner DJ (1988) Defensive chemicals of the Spanish dancer nudibranch Hexabranchus sanguineus and its egg ribbons: macrolides derived from a sponge diet. J Exp Mar Biol Ecol 119:99-109

Pawlik JR, Chanas B, Toonen RJ, Fenical W (1995) Defenses of Caribbean sponges against predatory reef fish. I. Chemical deterrency. Mar Ecol Prog Ser 127:183-194

Editorial responsibility: Otto Kinne (Editor), Oldendorf/Luhe, Germany
Pennings SC, Carefoot TH (1995) Post-ingestive consequences of consuming secondary metabolites in sea hares (Gastropods: Opisthobranchia). Comp Biochem Physiol C 111:249-256

Poulet SA, Ianora A, Miralto A, Meijer L (1994) Do diatoms arrest embryonic development in copepods? Mar Ecol Prog Ser 111:79-86

Pulitzer-Finali G (1986) A collection of West Indian Demonspongiae (Porifera). Annali Mus Civ Stor Nat Giacomo Doria 86:65-216

Rogers SD, Paul VJ (1991) Chemical defenses of three Glossodoris nudibranchs and their dietary Hyrtios sponges. Mar Ecol Prog Ser 77:221-232

Sokal RR, Rohlf FJ (1981) Biometry. The principles and practice of statistics in biologica/research, 2nd edn. WH Freeman \& Co, New York

Stead P, Hiscox S, Robinson PS, Pike NB, Sidebottom PJ, Roberts AD, Taylor NL, Wright AE, Pomponi SA, Langley D (2000) Eryloside F, a novel penasterol disaccharide possessing potent thrombin receptor antagonist activity. Bioorg Med Chem Lett 10:661-664

Stonik VA, Elyakov GB (1988) Secondary metabolites from echinoderms as chemotaxonomic markers. In: Scheuer PJ (ed) Bioorganic marine chemistry, Vol 2. Springer-Verlag, Berlin, p 59-86

Thompson JE, Walker RP, Faulkner DJ (1985) Screening and bioassays for biologically-active substances from forty marine sponge species from San Diego, California, USA. Mar Biol 88:11-21

Wiedenmayer F (1977) Shallow-water sponges of the western Bahamas. Experientia (Suppl) 28:1-287

Wilson DM, Puyana M, Fenical W, Pawlik JR (1999) Chemical defense of the Caribbean reef sponge Axinella corrugata against predatory fishes. J Chem Ecol 25:2811-2823

Zar JH (1984) Biostatistical analysis, 2nd edn. Prentice Hall, Englewood Cliffs, NJ

Submitted: December 13, 1999; Accepted: May 11, 2000 Proofs received from author(s): October 18, 2000 